\title{
BACTERIAL EXTRACELLULAR POLYMERIC SUBSTANCE (EPS): A CARRIER OF HEAVY METALS IN THE MARINE FOOD-CHAIN.
}

\section{P. V. Bhaskar* and Narayan B Bhosle. National Institute of Oceanography, Dona Paula, GOA-403 004.}

\begin{abstract}
The ecological implications of metal binding properties of bacterial EPS and its possible role in the bioaccumulation of pollutants in the marine food-chain was investigated using a partially purified and chemically characterized microbial EPS isolated from a species of Marinobacter. Various factors influencing metal sorption by the EPS including the influence of initial metal concentrations, incubation time, $\mathrm{pH}$ and sodium chloride concentrations on binding of lead $\left(\mathrm{Pb}^{++}\right)$and copper $\left(\mathrm{Cu}^{++}\right)$were evaluated. The bacterial EPS selectively bound more amount of $\mathrm{Cu}^{2+}$ per mg of EPS than $\mathrm{Pb}^{2+}$. Both copper and lead were sorbed more at near neutral $\mathrm{pH}$ than acidic $\mathrm{pH}$. The sorption of $\mathrm{Cu}^{2+}$ increased with increasing copper concentration. The estimated maximum binding ability (MBA) of the EPS was $182 \mathrm{nmol}$ copper and $13 \mathrm{nmol}$ lead $\mathrm{mg}^{-1}$ EPS. However, the sorption of these metals decreased with the increase in sodium chloride concentration. Furthermore, up to $35 \%$ of ${ }^{14} \mathrm{C}$-labeled Marinobacter was ingested by a benthic polychaete Hediste diversicolor. On an average, 29\% of the ingested EPS was absorbed into tissues and $49 \%$ of the EPS was respired. It was apparent that the animals used the EPS as a source of energy and nutrition. The labile nature of the bacterial EPS and its ability to bind heavy metals might route the bound metals through the marine food chain, thereby transferring and aiding bioaccumulation of metal pollutants in the higher trophic animals.
\end{abstract}

Keywords: Extracellular polymeric substances, EPS, metal binding, lead, copper, polychaete.

*Corresponding author

e-mail:pbhaskar@darya.nio.org

phone: 091-832-2450255

facsimile: 091-832-2450602/607. 


\section{INTRODUCTION}

In aquatic environments, bacterial extracellular polymeric substances (EPS) exist as a part of dissolved organic matter (DOM; Lignell 1990) and in particulate matter such as marine snow, microbial mats, biofilms etc. (Decho 1990 \& 2000, Passow et al. 1994). EPS generally contains high molecular weight compounds with charged functional groups and possess both adsorptive and adhesive properties. Due to the presence of charged moieties, EPS ideally serves as a natural ligand source, providing binding sites for other charged particles/molecules including metals (Decho 1990). The metal binding properties of microbial EPS is well-studied (Mittelman and Geesey 1985, Geesey et al. 1988) and EPS is widely employed in bioremediation of heavy metals including Pb, Ni, Cd, etc. (Brown \& Lester 1982, Loaëc et al. 1997, Dong et al. 2000).

In the marine environment, binding of heavy metals by microbial EPS (dissolved or particulate) can have far-reaching implications on its dynamics, removal of these metals from water column and subsequent transfer to marine organisms (Buffle et al. 1998). EPS have greater binding capacity for metals than any other known mineral sorbent (Quigley et al. 2002) and form multiple complexes with metal ions. On the other hand, higher animals are unable to directly absorb dissolved metals in their tissues. However, the presence of a labile and adsorptive bacterial EPS helps to immobilize the dissolved metals and make it available to animals (Selck et al. 1999). EPS plays an important role in supplementing the carbon demand of many organisms that feed on aggregates (Decho and Moriarty 1990), microbial mats and biofilms (Baird and Thistle 1986, Hoskins et al. 2003). While feeding, these organisms also ingest toxic heavy metals adsorbed to the EPS along with the cells and other organic matter, thereby causing bioaccumulation of these metals in the tissues of the feeders (Harvey and Luoma 1985, Decho and Lopez 1993).

The use of radioisotope labeled substrates has helped to better understand the uptake of EPS and its role in the bioaccumulation of metals in the deposit feeders. Direct evidences of metal accumulation by feeders has been carried out using labeled metals but these studies are limited (Decho and Lopez 1993, Schlekat et al. 1999, Selck et al. 
1999). Therefore, alternate methods like assessing the labile nature of metal binding EPS might be indirectly helpful to understand the role of EPS as a carrier of metals in the marine environment. Keeping in mind the usefulness of bacterial EPS in the bioremediation of metals and its significance in the marine food chain, studies were carried out to primarily assess the role of a bacterial EPS in the binding of heavy metals namely copper and lead. The effect of various factors such as $\mathrm{pH}$ and sodium chloride concentrations on binding of these metals were also evaluated. Experiments were also designed to assess the role of EPS as a source of nutrition for a benthic polychaete Hediste diversicolor and examine its significance as a vector of heavy metals in the marine food-chain.

\section{MATERIALS \& METHODS}

\section{Production and isolation of bacterial EPS}

In order to produce EPS for the metal binding experiments, cells of Marinobacter $\mathrm{sp}$. were grown in 21 flasks containing 11 of the Basal salt solution (BSS) $(3.5 \% \mathrm{NaCl}$, $0.7 \% \mathrm{MgSO}_{4}, 0.07 \% \mathrm{KCl}, 0.1 \% \mathrm{NH}_{4} \mathrm{Cl}, 10 \% \mathrm{~K}_{2} \mathrm{HPO}_{4} 700 \mu 110 \% \mathrm{~K}_{2} \mathrm{HPO}_{4}, 300 \mu \mathrm{l}$ $10 \% \mathrm{KH}_{2} \mathrm{PO}_{4}, \mathrm{pH} 7.6$ ) supplemented with $3 \%$ glucose, $0.05 \%$ peptone and $0.01 \%$ yeast extract. The culture was grown at $30^{\circ} \mathrm{C} \pm 0.5^{\circ} \mathrm{C}$ over a period of 14 days under static condition. For the production of labeled EPS, the bacterial isolate was grown in similar conditions for $72 \mathrm{~h}$. Thereafter, $1 \mathrm{ml}$ of ${ }^{14} \mathrm{C}$-glucose $\left(100 \mathrm{mCi} \mathrm{ml}^{-1}\right.$; Specific Activity $11470 \mathrm{mCi} / \mathrm{mmole}$ ) was added to the culture and the culture was further incubated for $24 \mathrm{~h}$.

At the end of the respective incubation period, cells were harvested and EPS was extracted and concentrated following Underwood et al. (1995). Briefly, EPS was isolated by centrifuging the cells at $10,000 \mathrm{rpm}$ at $4^{\circ} \mathrm{C}$ for $30 \mathrm{~min}$. The supernatant was decanted and the cell pellet treated with $10 \mathrm{mM}$ EDTA, vortex mixed for $15 \mathrm{~min}$ and recentrifuged at $10,000 \mathrm{rpm}$ (at $4^{\circ} \mathrm{C}$ for $20 \mathrm{~min}$ ) to extract cell-bound EPS. The cellbound EPS was pooled with the supernatant, filtered through $0.22 \mu \mathrm{m}$ filters and concentrated at $35^{\circ} \mathrm{C}$ using a rotary evaporator. The concentrated EPS was then precipitated using chilled ethanol (Bhosle et al. 1995), the precipitates redissolved in a 
small volume of deionized water and dialyzed using $8 \mathrm{kDa}$ MW cut-off dialysis bags. The dialysate was then reprecipitated and centrifuged at $3000 \mathrm{rpm}$ at $4{ }^{\circ} \mathrm{C}$ for $10 \mathrm{~min}$, lyophilized and stored at $-20^{\circ} \mathrm{C}$ until used for the experiments described below .

\section{Preparation of metal solutions}

Stock solutions having $40 \mathrm{mM}$ copper and $100 \mathrm{mM}$ lead were prepared by dissolving appropriate quantities of copper sulphate and lead acetate in deionized water, respectively. The stocks were stored at $4^{\circ} \mathrm{C}$ and working solutions of required concentrations were obtained by appropriate dilution in deionized water prior to each experiment.

\section{Metal binding by EPS}

Prior to each metal-binding experiment, a known amount of bacterial EPS was dissolved in a known volume of deionized water to give a final concentration of $5.6 \pm$ $0.34 \mathrm{mM}-\mathrm{C}$. Two $\mathrm{ml}$ of this solution was taken in $8 \mathrm{kDa}$ molecular weight cut-off dialysis bag and suspended in wide mouthed acid-cleaned polyvinyl chloride (PVC) containers having desired concentrations of copper or lead solutions. The metal solutions with the bags were incubated at $28 \pm 2{ }^{\circ} \mathrm{C}$ on a shaker at $220 \mathrm{rpm}$. After incubation, the dialysis bags containing the EPS were removed from the PVC containers and transferred to another PVC container having deionised water. Samples were dialyzed overnight to remove any loosely bound metal ions. The metal complexed polymer solution was then transferred to clean plastic vials and stored at $-20^{\circ} \mathrm{C}$ prior to analysis. For blanks, the bacterial polymer was replaced with equal volume of deionised water and incubated under similar conditions. Similarly, bacterial EPS without metal treatment was incubated in deionized water and used as control.

\section{Optimization of incubation time}

The dialysis bags containing bacterial EPS were suspended in wide-mouthed PVC bottles having solution of copper $(40 \mathrm{mM})$ or lead $(10 \mathrm{mM})$ and incubated as mentioned 
above. Dialysis bags were retrieved after 40, 60, 70, 80, 120, 160, 200 and $240 \mathrm{~min}$, dialyzed as above and analyzed for metal bound to EPS.

\section{Effect of initial metal ion concentration}

Bacterial EPS taken in dialysis bags were suspended in varying concentrations of copper (4 to $13 \mathrm{mg} \mathrm{l}^{-1}$ ) and lead (1.3 to $13 \mathrm{mg} \mathrm{l}^{-1}$ ) solutions and incubated for $120 \mathrm{~min}$. After the incubation period, the EPS was dialyzed against deionized water and analyzed for bound metal ions.

\section{Effect of $\mathrm{pH}$ and sodium chloride}

The copper $\left(4 \mathrm{mg} \mathrm{l}^{-1}\right)$ and lead $\left(10 \mathrm{mg} \mathrm{l}^{-1}\right)$ solutions of varying $\mathrm{pH}$ range (4 to 7.5 ) prepared in deionized water was obtained with $1 \mathrm{~N} \mathrm{NaOH}$. Similarly, solution of copper $\left(4 \mathrm{mg} \mathrm{l}^{-1}\right)$ and lead $\left(10 \mathrm{mg} \mathrm{l}^{-1}\right)$ were prepared in different concentrations of sodium chloride solution ( $0 \%$ to $3.5 \%$ ). The metals were allowed to adsorb onto the bacterial EPS suspended in dialysis bags for $120 \mathrm{~min}$, washed against deionized water and analyzed for bound metals. The $\mathrm{pH}$ of the metal solutions in the sodium chloride experiment was adjusted to 7 using $1 \mathrm{~N} \mathrm{NaOH}$.

\section{Analyses of metals bound to EPS}

The concentrations of copper and lead in the samples, control and blanks were measured using a double beam atomic absorption spectrophotometer (GBC-902 model; GBC Scientific Inc., USA). Calibration of instrument was carried out by analyzing the absorption of increasing concentrations of lead acetate and copper sulphate solutions. All the analyses were carried out in duplicate. 
Estimation of maximum binding ability (MBA)

The maximum binding ability (MBA) of the polymer for copper and lead was estimated from the langmuir plots drawn between the ratio of free ions to bound ions $\left(\mathrm{mg}^{-1}\right)$ against the available free ions using the equation

$c / x=1 / k_{1} k c+c / k_{1} ;($ Mittleman and Geesey 1985)

where $c$ is the free ion concentration, $x$ is the bound ion concentration, $k_{l}$ is maximum binding ability (MBA) and $k c$ is the conditional stability constant.

\section{EPS feeding experiment}

Hediste diversicolor (O.F. Müller 1776) (Phylum: Annelida, Class: Polychaeta, Family: Nereididae), a sediment dwelling omnivorous polychaete that inhabits intertidal muddy substrata in the temperate waters of northwest Europe was used to evaluate the importance of bacterial EPS as a carbon source. The animal displays both filter feeding and deposit feeding behavior depending upon the amount of phytoplankton in the overlying waters (Riisgård 1991, Costa et al. 2000). The animals were collected from the intertidal sediments at Dornumerseil, northern German coast (Fig. 1) and maintained in an aquarium in the laboratory. Prior to the feeding experiment, the animals were rinsed with filtered seawater $(0.22 \mu \mathrm{m})$ to remove the adhered mucus and sediment and weighed.

\section{Preparation of the labeled feed}

Sediment collected from the animal collection site was sieved to obtain an average grain size in the range of $250-500 \mu \mathrm{m}$. The sediment was made organic-free following the hydrogen peroxide and $\mathrm{Na}_{4} \mathrm{P}_{2} \mathrm{O}_{7} \cdot \mathrm{H}_{2} \mathrm{O}$ treatment as mentioned by Decho and Lopez (1993). The sediment was rinsed with distilled water, dried at $100^{\circ} \mathrm{C}$ and ground with a pestle and mortar before using it in feeding experiment. 
In order to prepare the feed, $50 \mu \mathrm{l}$ of the ${ }^{14} \mathrm{C}$-labeled EPS solution $(\sim 811 \mathrm{dpm})$ was mixed with $\sim 300 \mathrm{mg}$ sediment. The sediment-polymer mix was oven dried at $50^{\circ} \mathrm{C}$, rinsed with $200 \mu \mathrm{l}$ of sterile seawater and centrifuged at $1000 \mathrm{rpm}$ to remove loosely bound labeled EPS. The supernatant was discarded and the sediment coated with labeled EPS (242 dpm) was used as a feed during the feeding experiments.

\section{Experimental setup}

A schematic representation of the experimental setup is shown in Fig. 2. Seven test animals were fed labeled-EPS for $24 \mathrm{~h}$ followed by $24 \mathrm{~h}$ of depuration. Six live animals unexposed to the labeled substrate were used as the negative control. Similarly, six formalin-killed animals exposed to labeled feed for $24 \mathrm{~h}$ were used as whole body controls. The negative controls were used as blanks and subtracted from the respective samples in both test and whole body controls.

The animals were fed sediment following the method described by Meziane and Thorin (1998). The test animals were transferred to sterile petri plates containing $20 \mathrm{ml}$ of 0.22 $\mu \mathrm{m}$ filtered seawater and $300 \mathrm{mg}$ of ${ }^{14} \mathrm{C}$-labeled EPS coated sediment. Small quantities of dry powdered algae were also added to each petri-plate to facilitate the feeding. All the animals (tests and controls) were incubated at $15^{\circ} \mathrm{C}$ for $24 \mathrm{~h}$ to feed on sediment coated with labeled EPS after which animals from each petri-plate were removed and transferred to sterile petri-plates containing only $20 \mathrm{ml}$ of filtered seawater $(0.22 \mu \mathrm{m})$ and allowed to depurate for another $24 \mathrm{~h}$.

\section{Sampling and Analyses}

Fecal matter and respiration samples were collected after both hot feeding and depuration period. The amount of labeled carbon respired was determined by phenyl ethylamine method, wherein the labeled $\mathrm{CO}_{2}$ was trapped in filter papers soaked in phenyl ethylamine and then transferred into clean scintillation vials. Similarly, the fecal matter was transferred into scintillation vials using Pasteur pipettes and measured for the amount of label excreted. In order to evaluate the amount of label retained in the 
tissues, the controls and test animals were killed with formalin, dissolved in low quenching tissue solubilizer before transferring the samples to scintillation vials. The isotopic counts were carried out on Wallac-2000 scintillation counter.

${ }^{14} C$-EPS in tissues after hot feeding

The amount of EPS retained by the tissues was estimated as follows

${ }^{14} \mathrm{C}$-EPS in tissues after feeding $=\left[{ }^{14} \mathrm{C}\right.$-EPS respired $+{ }^{14} \mathrm{C}$-EPS in tissues $]$ after depuration

Assimilation efficiency

The amount of EPS assimilated (respired and in tissues) by the animals was estimated as

$1-\left[{ }^{14} \mathrm{C}\right.$-fecal matter $] \times 100=\% A E$ (Decho and Lopez 1993)

$\left[{ }^{14} \mathrm{C}\right.$-ingested $]$

and the total label ingested by the organism was estimated as

${ }^{14} \mathrm{C}$-ingested $={ }^{14} \mathrm{C}$-respired $+{ }^{14} \mathrm{C}$-in fecal matter $+{ }^{14} \mathrm{C}$-in tissues.

\section{RESULTS}

Influence of incubation time on metal-binding by EPS

The optimal incubation time for the maximal sorption of both copper $(40 \mathrm{mM})$ and lead (100 mM) ions was $120 \mathrm{~min}$. Concentrations of copper ions adsorbed by the EPS increased with time to reach a high of $334 \pm 6 \mu \mathrm{g} \mathrm{mg}^{-1}$ EPS (Fig. 3a). A similar adsorption pattern was also observed for lead with the maximal adsorption (70 $\pm 7 \mu \mathrm{g}$ $\mathrm{mg}^{-1}$ EPS) after $120 \mathrm{~min}$ of incubation (Fig 3b). 


\section{Effect of initial metal ion concentration}

Equilibrium isotherms plotted between the amount of copper and lead adsorbed by the EPS against initial metal concentration (Fig. 4). The amount of lead adsorbed by the EPS was lower than copper and reached state of equilibrium $\left(39 \pm 2 \mu \mathrm{g} \mathrm{mg}^{-1}\right.$ EPS $)$ at an initial lead concentration of $5 \mathrm{mg} \mathrm{l}^{-1}$. On the other hand, the amount of copper adsorbed increased with increasing copper concentrations and varied from $139 \pm 6 \mu \mathrm{g} \mathrm{mg}^{-1}$ EPS at $4 \mathrm{mg} \mathrm{l}^{-1}$ copper concentration to $189 \mu \mathrm{g} \mathrm{mg}^{-1}$ EPS at $10 \mathrm{mg} \mathrm{l}^{-1}$ copper concentration. The maximum binding ability of the EPS for copper and lead calculated from the langmuir's linear plot (Fig. 5) was $182 \mathrm{nmol} \mathrm{mg}^{-1}$ and $13 \mathrm{nmol} \mathrm{mg}^{-1}$ carbohydrate, respectively.

\section{Effect of $p H$}

Relatively higher amounts of both copper and lead were adsorbed to EPS at near neutral $\mathrm{pH}$ than at acidic $\mathrm{pH}$. The amount of copper adsorbed to the EPS showed an increase from $139 \pm 6 \mu \mathrm{g} \mathrm{mg}^{-1}$ EPS at $\mathrm{pH} 4.5$ to $193 \mu \mathrm{g} \mathrm{mg}^{-1}$ EPS at $\mathrm{pH} 7$ (Fig. 6). Similarly, the amount of lead adsorbed by the EPS increased from $146 \pm 7 \mu \mathrm{g} \mathrm{mg}^{-1}$ EPS at $\mathrm{pH} 4.5$ to $219 \pm 2 \mu \mathrm{g} \mathrm{mg}^{-1} \mathrm{EPS}$ at $\mathrm{pH} 7$.

\section{Effect of sodium chloride}

The presence of sodium chloride drastically decreased the amount of copper and lead adsorbed by the EPS. In the absence of sodium chloride, the amount of copper and lead adsorbed was $257 \pm 0.6 \mu \mathrm{g} \mathrm{mg}^{-1}$ EPS and $87 \pm 3.3 \mu \mathrm{g} \mathrm{mg}^{-1}$ EPS, respectively. However, a sharp decrease in the amount of copper $\left(125 \pm 3 \mu \mathrm{g} \mathrm{mg}^{-1}\right.$ EPS $)$ and lead $(22 \pm 1 \mu \mathrm{g}$ $\mathrm{mg}^{-1}$ EPS) adsorbed by the EPS was observed at $1 \%$ sodium chloride concentration (Fig. 7). Therafter, the amount of copper or lead bound by EPS showed small-scale variations with increasing sodium chloride concentrations. 
At the end of the feeding experiment, the amount of ${ }^{14} \mathrm{C}$-EPS ingested varied from 28 dpm to $115 \mathrm{dpm}$ (Table 1). During the feeding experiment, the amount of labeled carbon respired ranged from $8 \mathrm{dpm}$ to $104 \mathrm{dpm}$ of ${ }^{14} \mathrm{CO}_{2}$. Similarly, the amount of labeled carbon in the fecal matter and in the tissues of the animals ranged from 11 to 38

$\mathrm{dpm}$ and undetectable to $46 \mathrm{dpm}$, respectively (Table 1). The absorption efficiency of the animals ranged from 48 to $90 \%$ and the mean absorption efficiency was $66 \pm 15 \%$ (Table 1).

The percent contribution of the different fractions of labeled carbon to the total ingested labeled carbon is shown in Table 2. At the end of the experiment, the percent labeled carbon respired, excreted and retained in the tissues ranged from $11 \%$ to $90 \%$ (average: $47 \pm 29 \%$ ), 10 to $52 \%$ (average: $35 \pm 15 \%$ ) and undetectable levels to $60 \%$ (average: $29 \pm 23 \%$ ) of the total ingested labeled carbon, respectively. In comparison to the test animals, the amount of isotope retained by formalin-killed animals exposed by direct absorption into the tissues was negligible and detected in only 2 out of 6 animals (data not shown). Except with respired labeled carbon $(\mathrm{r}=0.840 ; \mathrm{p}<0.01)$, there was no significant correlation between isotope ingestion and other parameters. One-way ANOVA of labeled EPS retained in the tissues of live test animals and whole body control animals showed significant variance between the two sets $(F s=11.3 ; p<0.01)$.

\section{DISCUSSION}

Most of the higher organisms tend to accumulate heavy metals by ingesting metals bound to particles and/or sediments (Decho 1990). The bioavailability of the heavy metals like copper and lead to the higher organisms depends upon the mobilization of these metals between the dissolved and particulate phase within the sediments. Nonhumic organic matter like EPS serve as natural ligands that bind metals and are assimilable, thereby increasing the chances of metals accumulating in the marine foodchain (Roanne and Pepper 2000). The factors that control the transfer of these metals are the metal binding ability of the EPS and the labile nature. 
Bacterial exopolymer used in the present study showed distinct differences in its ability to bind copper and lead (Fig. 4). This is also reflected in the langmuir's linear isotherms obtained for the bacterial EPS (Fig. 5). At ambient $\mathrm{pH}$ of the metal solutions (without any $\mathrm{pH}$ adjustments), the amount of copper bound by the polymer was 3 folds greater than lead (Fig. 1). The ability of bacterial EPS to bind heavy metals like copper \& lead can have significant ecological implications. Both copper and lead are widely regarded as toxic metals for microorganisms (Ford et al. 1987). The greater affinity of EPS towards copper might help in the immobilization of copper in the natural environment, thereby protecting the cells from copper toxicity. However, the fate of EPS-bound metal might vary. The bound metals may get transported to deeper sediments through pore-water (Czajka et al. 1997). On the other hand, the bound EPS might get released into the surrounding waters due to changes in the physico-chemical characteristics of the environment.

Another factor that controls the uptake of metals is the binding ability of the EPS. The maximum amount of copper bound by the Marinobacter EPS $\left(189 \mu \mathrm{g} \mathrm{mg}^{-1}\right.$ EPS or $51 \pm$ $2 \mu \mathrm{g} \mathrm{mg}^{-1}$ carbohydrate; Fig. 4) was greater than those bound by a crude EPS of freshwater sediment bacterium (31 $\mu \mathrm{g} \mathrm{mg}^{-1}$ carbohydrate) (Mittleman and Geesey 1985) and Deleya marina (16.8 $\mu \mathrm{g} \mathrm{mg}^{-1}$ EPS) (Ford et al. 1987). In contrast to copper, the maximum amount of lead bound by the bacterial polymer was only $41.4 \mu \mathrm{g} \mathrm{mg}^{-1}$ EPS (Fig. 4), which was much lower than those reported for EPS isolated from sludge (64 $\mu \mathrm{g} \mathrm{mg}^{-1}$ EPS; Lopez et al. 1995) or deep-sea Alteromonas (316 $\mu \mathrm{g} \mathrm{mg}^{-1}$ EPS; Loaëc et al. 1997). Moreover, the maximum binding ability of the EPS for copper was higher by an order of magnitude than lead. Such greater binding ability of copper can increase the amount of bound metal transferred to higher animals. It is clear from our observations that the bacterial EPS in this study could definitely play an important role in influencing the fate of copper in the marine environment.

Binding of metals by organic compounds like bacterial EPS is influenced by various factors including $\mathrm{pH}$ and presence of other salts like sodium chloride. In the present study, both copper and lead were more effectively bound at neutral pH (Fig 6). Higher 
$\mathrm{pH}$ values could not be tested as the copper and lead solutions tend to precipitate on their own at $\mathrm{pH}>7.5$. Our findings were similar to those reported by Ferris et al. (1989), Loaëc et al. (1998) and Lores and Pennock (1998). The binding of metals at neutral $\mathrm{pH}$ carries significance since the culture was isolated from an estuarine environment, having a $\mathrm{pH}$ range of 6-8 (Manerikar 1998). The ambient copper concentrations (45.7 to $82.7 \mathrm{ppb}$; George 1993) in the estuarine waters off Goa are much lower than those used in the present study. Thus, organic ligands like bacterial EPS used in this study might selectively complex metals like copper in the estuarine waters over a wide $\mathrm{pH}$ range and may influence its distribution in these waters.

Presence of sodium chloride also regulates the concentrations of toxic metals like copper and lead in the ambient environment. The binding of $\mathrm{Cu}$ and $\mathrm{Pb}$ ions was maximal at $0 \%$ sodium chloride in the present study and reduced drastically at $1 \%$ sodium chloride concentration (Fig. 7). Similar decrease in binding of metals like copper, cadmium, chromium and zinc by dissolved organic matter with increasing salinity has been reported in estuarine waters (Lores and Pennock 1998). The interference of other metals during the metal sorption by polymer is well known (Xie et al. 1996, Lores and Penock 1998). The sharp decline in bound metal concentrations in the presence of $1 \%$ sodium chloride concentration could be due to complexation of copper and lead with chloride ions. Such process could lead to restricted availability of free copper/lead ion, thereby reduce the amount of copper/lead getting bound to the EPS. Although heavy metals like copper and lead are preferred and can displace competing alkaline earth metals like $\mathrm{Na}, \mathrm{K}, \mathrm{Ca}$ and $\mathrm{Mg}$ bound to the polymer (Lores and Pennock 1998, Haug and Smidsrod 1970), the presence of 1\% sodium chloride could restrict the binding of copper and lead to the polymer. Interestingly, the $\%$ metal removal did not vary much above $1 \%$ sodium chloride concentrations. The observed trends might be due to either specific binding sites of copper/lead ions and/or presence of multiple binding sites in the Marinobacter EPS.

Bacterial EPS in this study was ingested in varying amounts during the feeding experiment and the average isotope ingested $(77.6 \mathrm{dpm})$ was $32 \%$ of the total isotope fed $(242 \mathrm{dpm})$. Although the amount of EPS ingested during the experiment was 
relatively less, the absorption efficiency (\%AE) of the EPS was relatively high. The $\% \mathrm{AE}$ of the animals in the present study were similar to those reported for Streblopsio benedectii fed on slime EPS derived from marine pseudomonads (Decho and Lopez 1993). However, our observations cannot be generalized for other feeders and EPS derived from other bacteria since $\% \mathrm{AE}$ varies considerably amongst different animals (Harvey and Luoma 1984, Baird and Thistle 1986, Decho and Moriarty 1990).

The feeding experiment was carried out at in seawater having $\sim 35$ psu salinity. The presence of salts in natural waters might influence the complexation of metals with EPS and in turn might influence the \%AE of the EPS. For example, the \%AE of an amphipod was lower for EPS bound cadmium at $25 \mathrm{ppt}$ salinity than at $7.5 \mathrm{ppt}$ (Schlekat et al. 1999) due to partitioning of cadmium with decreasing salinity. However, a similar effect of salinity on the uptake and the fate of metal bound to EPS could not be ascertained in this study. Nevertheless, the amount of metals bound to the EPS was consistent at higher sodium chloride concentrations and therefore might be able to transfer the bound metals to the feeding animal.

On an average, respiration and assimilation in tissues accounted for $47 \%$ and $29 \%$ of ingested labeled carbon, respectively (Table 2). Our result was in contrast to the observations of Decho and Moriarty (1990) who reported only 14.6\% respiration loss of the bacterial EPS by copepods. Moreover, the labeled EPS respired by the animals in the present study had a positive relation with amount of the polymer ingested $(r=0.84$; $\mathrm{p}<0.01$ ) suggesting that the ingested EPS was used as an energy source. Significant differences in the amount of labeled EPS absorbed by the tissues $\left(F_{S}=11.3, \mathrm{p}<0.01\right)$ between the whole body controls and the whole body test samples suggests that most of the labeled EPS detected in the tissues was due to active feeding and assimilation of the EPS. Also, the fraction of EPS in the tissues (29\%) suggests that the feeding animals might assimilate any metal bound by the polymer. Thus, the ability of Marinobacter EPS to bind metals over a wide range of $\mathrm{pH}$ and sodium chloride concentrations combined with its labile nature make it a suitable vector for the transfer of the dissolved metals in to the marine food-chain. 


\section{CONCLUSIONS}

Marinobacter EPS served as natural organic ligand that could bind dissolved copper and lead under varying free metal ion concentrations and $\mathrm{pH}$. Presence of sodium chloride concentrations reduced the amount of metal bound to the EPS. The preference and high affinity for dissolved copper over lead might have significance in the cycling of these metal ions in the natural environments. Such affinity to toxic metals coupled with the labile nature of the Marinobacter EPS as observed from the feeding experiments points to the significance of the bacterial EPS as a potential vector for heavy metals in the marine food-chain.

\section{ACKNOWLEDGEMENTS}

We acknowledge the Director, National Institute of Oceanography, Dona Paula for his support and encouragement. The present study is a part of PVB's Doctoral Thesis work and the first author is grateful to CSIR, New Delhi, for the award of Senior Research Fellowship and financial assistance. The authors also acknowledge the German Academic Exchange Service (DAAD) for supporting this study under the UGC-DAAD fellowship. PVB is also thankful to Prof. Meinhard Simon of ICBM, Oldenburg and Dr. H P Grossart for logistic support for this work and Mr. Daniel Dotschkal for his help in the collection of animals. 


\section{REFERENCES}

Baird, B.H. and Thistle, D. Uptake of bacterial extracellular polymer by a depositfeeding holothurian (Isostichopus badionotus). Mar. Biol., 92: 183-187; 1986.

Bhosle, N.B., Sawant, S.S., Garg, A. and Wagh, A.B. Isolation and partial chemical analysis of exopolysaccharides from the marine fouling diatom Navicula subinflata. Bot. Mar., 38: 103-110; 1995.

Brown, M.J. and Lester, J.N. Role of bacterial extracellular polymers in metal uptake in pure bacterial culture and activated sludge-I. Effects of metal concentration. Wat. Res., 16: 1539-1558; 1982.

Buffle, J., Wilkinson, K.J., Stoll, S., Fillela, M. and Zhang, J. A generalized description of aquatic colloidal interactions: The three colloidal component approach. Environ. Sci. Technol., 32: 2887-2899; 1998.

Costa, P.F.E., Narciso, L. and da-Fonseca, L.C. Growth, survival and fatty acid profile of Nereis diversicolor (O. F. Müller, 1776) fed on six different diets. Bull. Mar. Sci., 67: 337-343; 2000.

Czajka, D.R., Lion, L.W., Shuler, M.L. and Ghiorse, W.C. Evaluation of the utility of bacterial extracellular polymers for treatment of metal contaminated soils: polymer persistence, mobility and the influence of lead. Wat. Res., 31: 2827-2839; 1997.

Decho, A.W. Microbial exopolymer secretions in ocean environments: Their role(s) in food webs and marine processes. In: Barnes, M., ed., Oceanogr. Mar. Biol. Annu. Rev., 28: pp. 73-153; 1990.

Decho, A.W. Microbial biofilms in intertidal systems: an overview. Cont. Shelf Res., 20: 1257-1273; 2000. 
Decho, A.W. and Moriarty, D.J.W. Bacterial exopolymer utilization by a harpacticoid copepod: A methodology and results. Limnol. Oceanogr., 35: 1039-1049; 1990.

Decho, A.W. and Lopez, G.R. Exopolymer microenvironments of microbial flora: Multiple and interactive effects on trophic relationships. Limnol. Oceanogr., 38: 1633$1645 ; 1993$.

Dong, D., Nelson, Y.M., Lion, L.W., Shuler, M.L. and Ghiorse, W.M. Adsorption of $\mathrm{Pb}$ and $\mathrm{Cd}$ onto metal oxides and organic material in natural surface coatings as determined by selective extractions: new evidence for the importance of $\mathrm{Mn}$ and Fe oxides. Wat. Res., 34: 427-436; 2000.

Ferris, F.G., Schultze, S., Witten, T.C., Fyfe, W.S. and Beveridge, T.J. Metal interactions with microbial biofilms in acidic and neutral $\mathrm{pH}$ environments. Appl. Environ. Microbiol., 55: 1249-1257; 1989.

Ford, T.E., Maki, J.S. and Mitchell, R. The role of metal-binding bacterial exopolymers in corrosion processes. Corrosion/87, Paper no. 380, NACE publications, California; 1987.

Geesey, G.G., Jang, L., Jolley, J.G., Hankins, M.R., Iwaoka, T. and Griffiths, P.R. Binding of metal ions by extracellular polymers of biofilm bacteria. In: Water and Wastewater Microbiology, Jenkins, D. and Olson, B.H., eds., 20: 161-165, 1988.

George, M.D. Speciation and behaviour of $\mathrm{Cd}, \mathrm{Pb}$ and $\mathrm{Cu}$ in the Zuary estuary, west coast of India. Ind. J. Mar. Sci., 22: 126-220; 1993.

Harvey, R.W. and Luoma, S.N. The role of bacterial exopolymers and suspended bacteria in the nutrition of the deposit feeding clam, Macoma balthica. J. Mar. Res., 42: 957-968; 1984. 
Harvey, R.W. and Luoma, S.N. Effects of adherent bacteria and bacterial extracellular polymers upon assimilation by Macoma balthica of sediment bound $\mathrm{Cd}, \mathrm{Zn}$ and $\mathrm{Ag}$. Mar. Ecol. Prog. Ser., 22: 281; 1985.

Haug, A. and Smidsrod, O. Selectivity of some anionic polymers for divalent metal ions. Acta. Chem. Scand., 240: 843; 1970.

Hoskins, D.L., Stancyk, S.E. and Decho, A.W. Utilization of algal and bacterial extracellular polymeric secretions (EPS) by the deposit-feeding brittlestar Amphipholis gracillima (Echinodermata). Mar. Ecol. Prog. Ser., 247: 93-101; 2003.

Lignell, R. Excretion of organic carbon by phytoplankton: Its relation to algal biomass, primary productivity and bacterial secondary productivity in the Baltic Sea. Mar. Ecol. Prog. Ser., 68: 85-99; 1990.

Loaëc, M., Olier, R. and Guezennec, J. Uptake of lead, cadmium and zinc by a novel bacterial exopolysaccharide. Wat. Res., 31: 1171-1179; 1997.

Loaëc, M., Olier, R. and Guezennec, J. Chelating properties of bacterial polysaccharides from deep-sea hydrothermal vents. Carbohy. Polymers, 35: 65-70; 1998.

Lopez F.A., Perez C, Sainz E and Alonso M. Adsorption of lead on blast furnace sludge. J. Chem. Tech. Biotechnol., 62: 200-206, 1995.

Lores, E.M. and Pennock, J.R. The effect of salinity on binding of $\mathrm{Cd}, \mathrm{Cr}, \mathrm{Cu}$ and $\mathrm{Zn}$ to dissolved organic matter. Chemosphere, 37: 861-874, 1998.

Manerikar, M. Behaviour of carbon dioxide in the Mandovi-Zuari estuarine complex, Goa. MSc Dissertation, Goa University, 1998. 
Meziane, T. and Thorin, S. Spatial analysis of macrozoobenthic community structure in Mont Saint Michel Bay, France. Technical report on the Macroinvertebrate Food-web, European Salt Marshes Modelling project. 1998.

Mittleman, M.W. and Geesey, G.G. Copper binding characteristics of exopolymers from a freshwater-sediment bacterium. Appl. Environ. Microbiol., 49: 846-851; 1985.

Passow, U., Alldredge, A.L. and Logan, B.E. The role of particulate carbohydrate exudates in the flocculation of diatom blooms. Limnol. Oceanogr., 41: 335-357; 1994.

Quigley, M.S., Santschi, P.H., Hung, C.C., Guo, L. and Honeyman, B.D. Importance of acid polysaccharides for ${ }^{234} \mathrm{Th}$ complexation to marine organic matter. Mar. Chem., 76: $27-45 ; 2002$.

Riisgård, H.U. Suspension feeding in the polychaete Nereis diversicolor. Mar. Ecol. Prog. Ser., 70: 29-37; 1991.

Roanne, T.M. and Pepper, I.L. Microorganisms and Metal Pollutants. In: Environmental Microbiology, Maier, R.M., Pepper, I.L. and Gerba, C.P., eds., Academic Press, San Diego, 2000.

Schlekat, C.E., Decho, A.W. and Chandler, G.T. Dietary assimilation of cadmium associated with bacterial exopolymer sediment coatings by the estuarine amphipod Leptocheirus plumulosus: effects of Cd concentration and salinity. Mar. Ecol. Prog. Ser., 183: 205-216; 1999.

Selck, H., Decho, A.W. and Forbes, V.E. Effects of chronic metal exposure and sediment organic matter on digestive absorption efficiency of cadmium by the depositfeeding polychaete Capitella species I. Environ. Toxicol. Chem., 18: 1289-1297; 1999. 
Underwood, G.J.C., Paterson, D.M. and Parkes, R.J. The measurement of microbial carbohydrate exopolymers from intertidal sediments. Limnol. Oceanogr., 40: 1243$1253 ; 1995$.

Xie, J.Z., Hsiao-Lung, C. and Kilbane-II, J.J. Removal and recovery of metal ions from wastewater using biosorbents and chemically modified absorbents. Biores. Tech., 57: 127-136; 1996. 
Table 1. The total amount of labeled EPS respired, excreted and retained in the tissues of the polychaete Hediste diversicolor during the feeding experiment.

\begin{tabular}{|c|c|c|c|c|c|}
\hline $\begin{array}{c}\text { Number of } \\
\text { animals }\end{array}$ & $\begin{array}{c}{ }^{14} \mathrm{C} \text {-ingested } \\
(\mathrm{dpm})\end{array}$ & $\begin{array}{c}{ }^{14} \mathrm{C}-\text { respired } \\
(\mathrm{dpm})\end{array}$ & $\begin{array}{c}{ }^{14} \mathrm{C} \text {-excreted } \\
(\mathrm{dpm})\end{array}$ & $\begin{array}{c}{ }^{14} \mathrm{C} \text { - in tissues } \\
(\mathrm{dpm})\end{array}$ & $\% \mathrm{AE}$ \\
\hline 1 & 95 & 61 & 26 & 8 & 72 \\
2 & 73 & 26 & 38 & 9 & 52 \\
3 & 28 & -- & 14 & 14 & 48 \\
4 & 77 & 8 & 23 & 46 & 70 \\
5 & 91 & 44 & 32 & 15 & 65 \\
6 & 115 & 104 & 11 & nd & 90 \\
7 & 64 & 39 & 20 & 5 & 68 \\
\hline
\end{tabular}

--: Sample lost; nd: not detected.

Table 2: Percent of ${ }^{14} \mathrm{C}$-labeled EPS respired, excreted, retained in tissues and absorption efficiency of the polychaete Hediste diversicolor.

\begin{tabular}{|c|c|c|c|}
\hline $\begin{array}{c}\text { Number of } \\
\text { animals }\end{array}$ & $\%{ }^{14} \mathrm{C}$-respired & $\%{ }^{14} \mathrm{C}$-excreted & $\%{ }^{14} \mathrm{C}$-retained \\
\hline 1 & 64 & 28 & 8 \\
2 & 34 & 49 & 9 \\
3 & -- & 52 & 48 \\
4 & 11 & 30 & 59 \\
5 & 48 & 35 & 17 \\
6 & 90 & 10 & nd \\
7 & 60 & 32 & 8 \\
\hline
\end{tabular}

--: Sample lost; nd: not detected. 


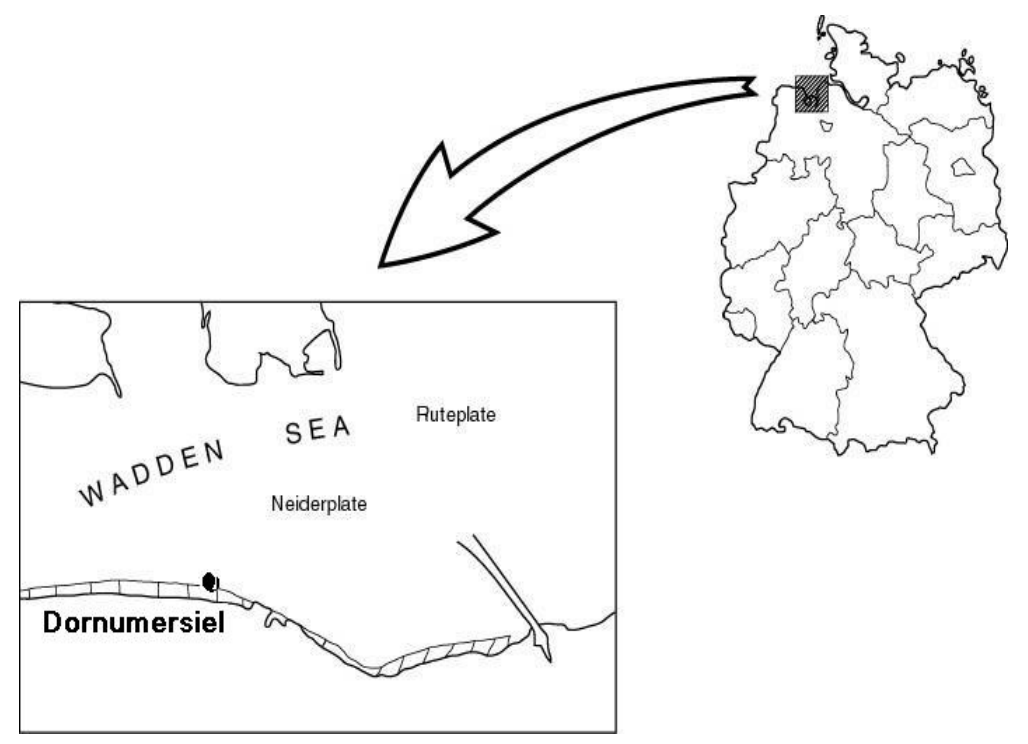

Fig. 1 Site chosen for the collection of the polychaete $N$. diversicolor for the feeding experiment. 


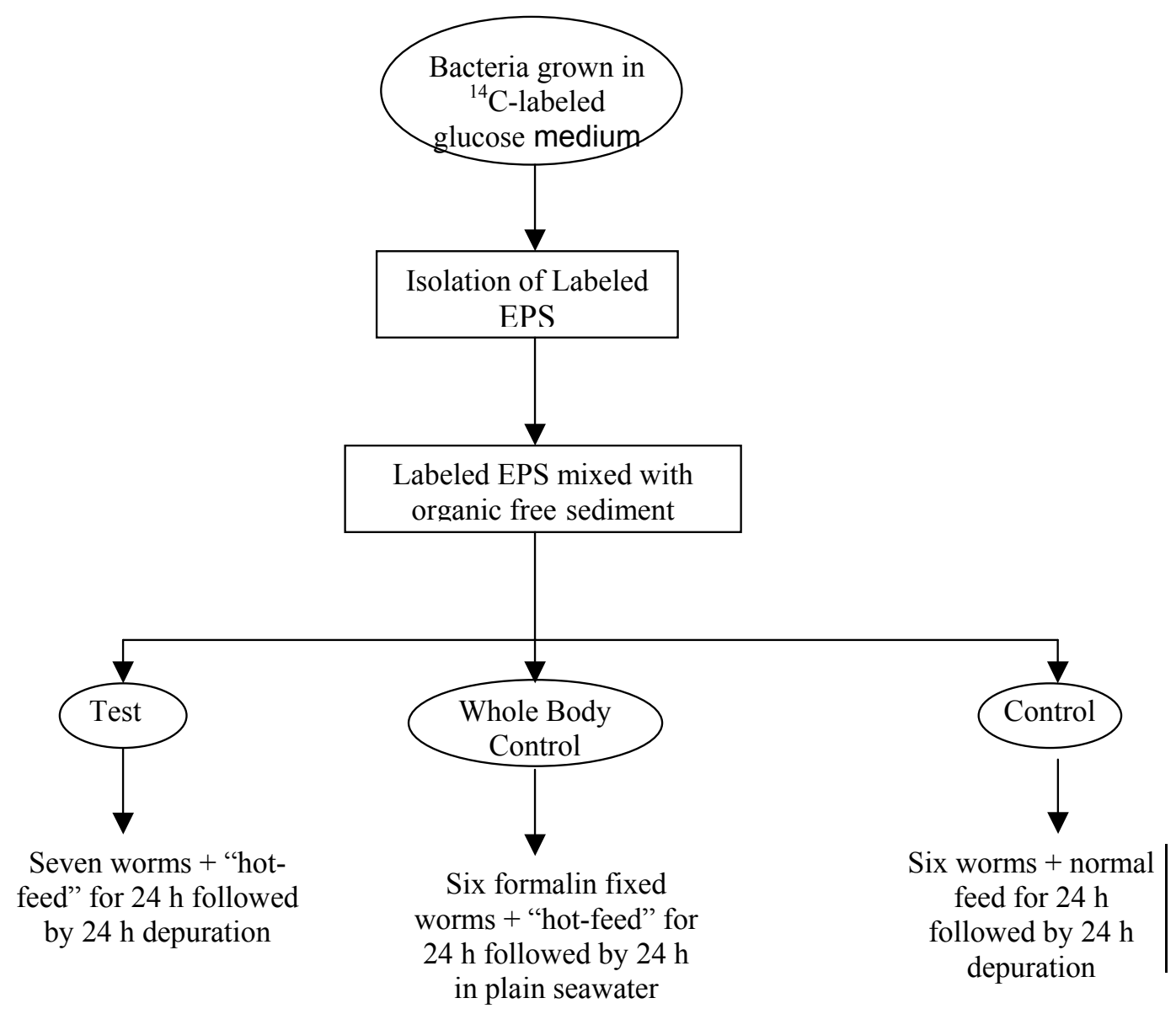

Fig. 2. A schematic representation of the experimental set-up used during the feeding experiment. 

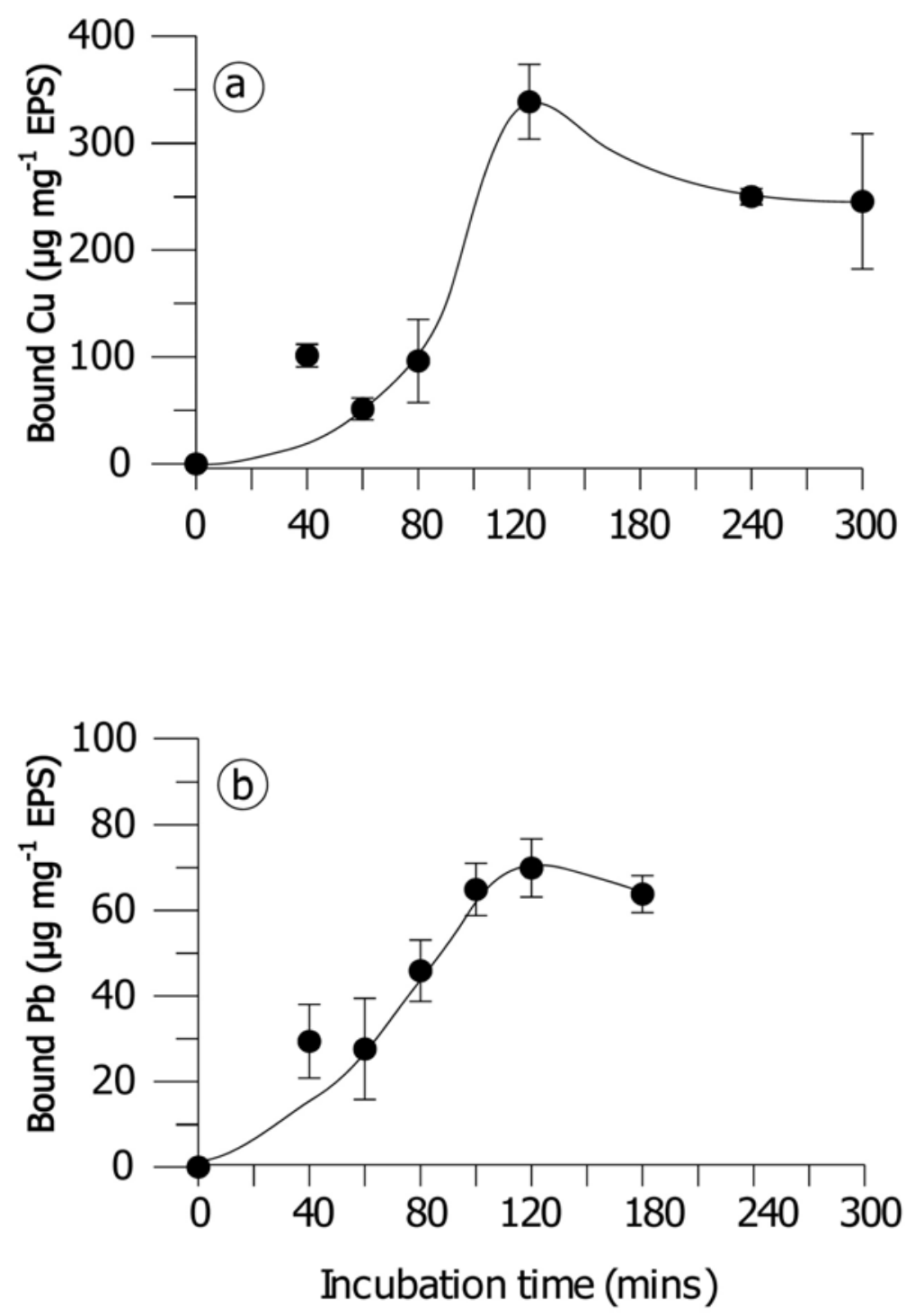

Fig. 3. Effect of incubation time on the binding of copper and lead to Marinobacter EPS. 


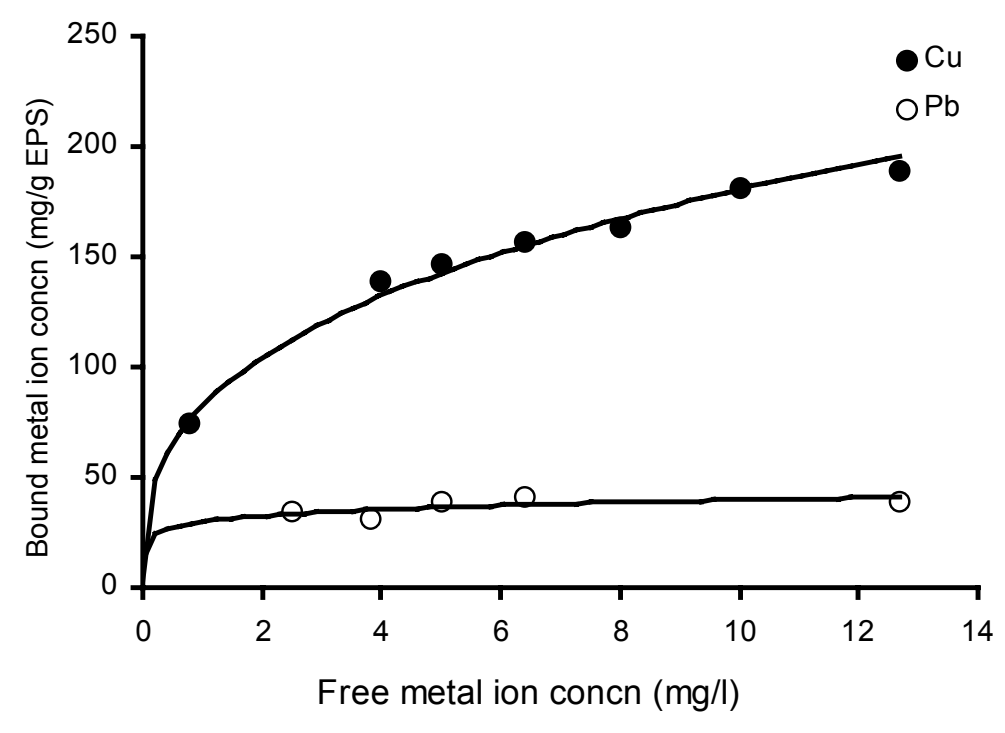

Fig. 4. Absorption isotherms of copper and lead in presence of increasing metal ion concentrations. 


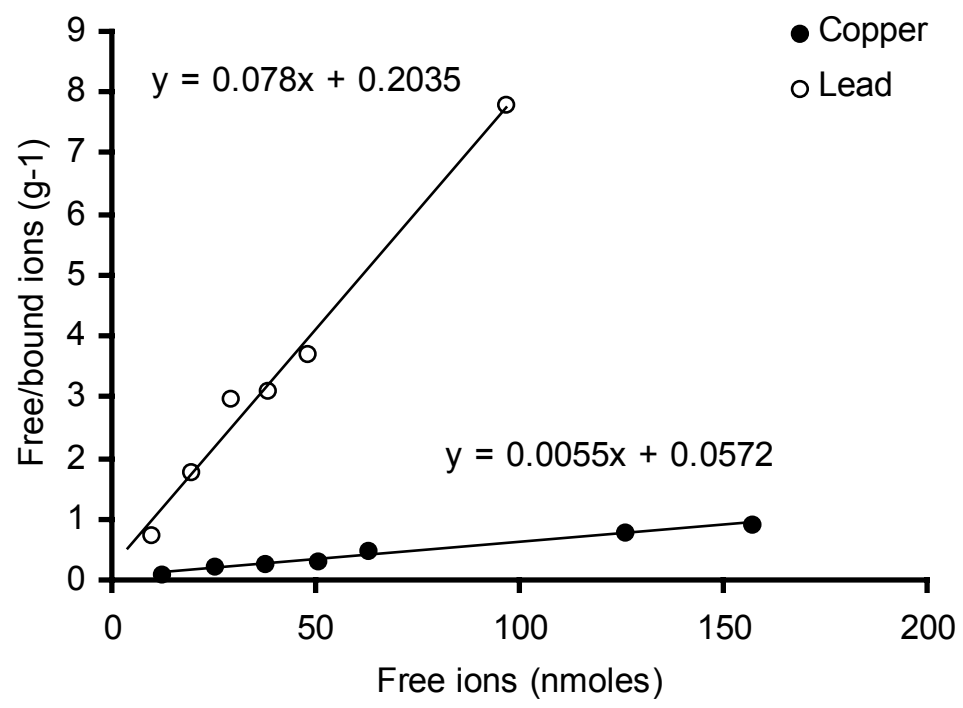

Fig. 5. Langmuir plot of free/bound ions of copper and lead against free metal ions. 


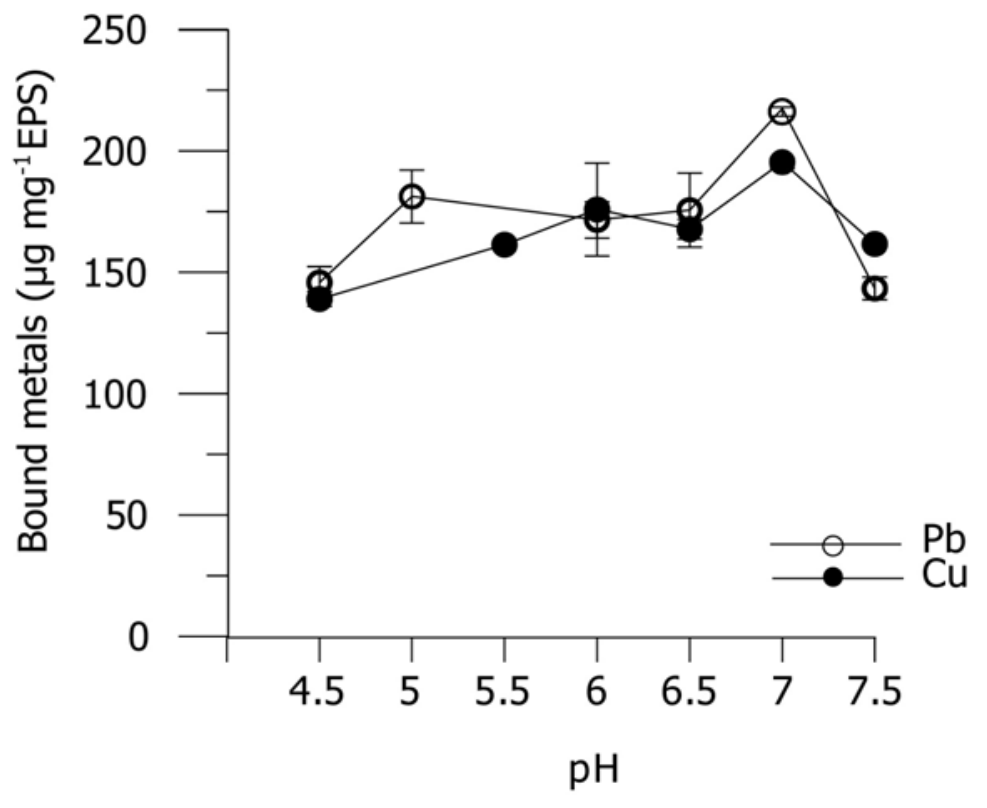

Fig. 6. Effect of increasing pH on the binding of copper and lead by Marinobacter EPS. 


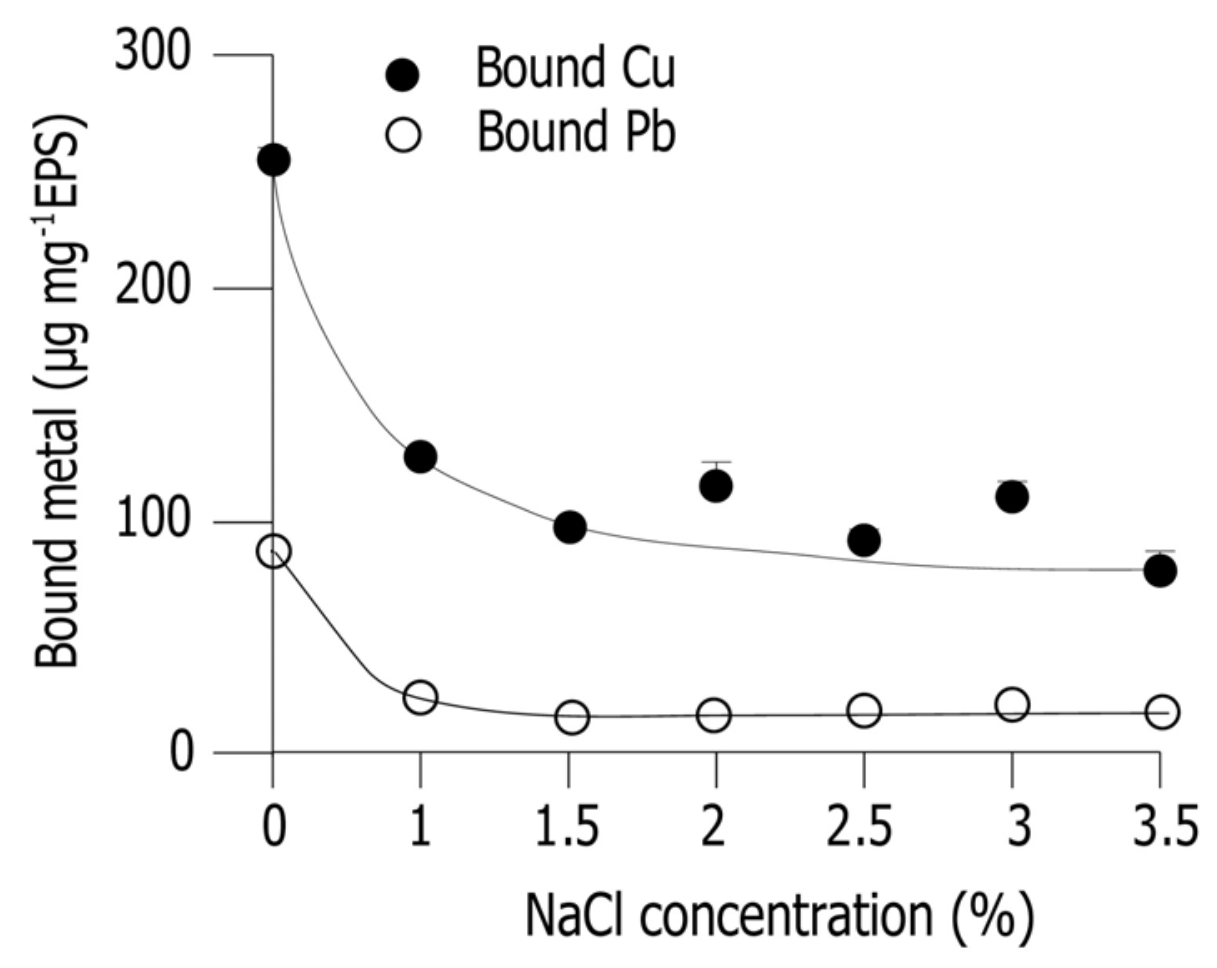

Fig. 7. Effect of increasing sodium chloride concentration on the binding of copper and lead by Marinobacter EPS. 
